AGRICULTURE AND BIOLOGY JOURNAL OF NORTH AMERICA

ISSN Print: 2151-7517, ISSN Online: 2151-7525, doi:10.5251/abjna.2011.2.6.921.928

(C) 2011, ScienceHu $\beta$, http://www.scihub.org/ABJNA

\title{
Influence of weeding regime and neem seed extract on the population of insect pests and yield of cabbage in the Guinea savannah zone
}

\author{
${ }^{1}$ I. K. Dzomeku, ${ }^{2} \mathrm{M}$. Abudulai and ${ }^{1} \mathrm{M}$. Abukari \\ ${ }^{1}$ Department of Agronomy, Faculty of Agriculture, University for Development Studies. \\ Tamale; ${ }^{2}$ Savannah Agricultural Research Institute. P. O. Box 52. Tamale.
}

\begin{abstract}
This experiment was conducted during the 2005 and 2006 cropping seasons at the research field of the Faculty of Agriculture, University for Development Studies, on Nyankpala campus near Tamale in the Guinea savannah zone of Ghana. The objectives of the study were to determine the influence of weeding regime and application of neem seed extract (NSE) on insect pest populations and yield of cabbage. The experiment was a $3 \times 5$ factorial laid out in randomized complete block design with three replications. The treatments consisted of: hoe weeding every 2 or 3 weeks and unweeded control combined with applications of NSE at $2 \%(\mathrm{w} / \mathrm{v}), 5 \%$ and $10 \%$, and Karate 2.5 EC (Lambda cyhalothrin) and water-treated control. The results indicated the occurrence of broadleaves, grasses, sedges and shrubs in order of dominance as weed species. Insect species prevalent included grasshoppers (Zonocerus variegatus [L.]), crickets (Gryllus spp.), caterpillars of diamondback moth (Plutella xylostella L.), cabbage webworm (Hellula undalis F.), and flea beetles (Phyllotreta cruciferae [Goeze]). Snails (Helix pomatia L.) were the other prevalent pests recorded. Weed biomass was affected only by weeding regime and was highest on control plots followed by plots weeded every 3 weeks and every 2 weeks, respectively. Weeding regime significantly affected the populations of insect pests on cabbage. Hoeing every 2 or 3 weeks lowered pest populations with consequent stability in plant population and increased cabbage yield more than the control plots. The 10\% NSE was highly effective and gave better protection to cabbage plants against pest damage than the $5 \%$ NSE, Karate, $2 \%$ NSE and watertreated control with corresponding increase in yield and cosmetic beauty of cabbage heads. Overall however, between $5 \%-10 \%$ NSE can be used as an alternative to the synthetic insecticide Karate to control insect pests of cabbage. Also, weeding every 3 weeks was adequate to avoid yield loss due to weed competition.
\end{abstract}

\section{INTRODUCTION}

Cabbage (Brassica oleracea var capitata) is grown for its fleshy leaves, which may be served raw or in boiled form. In Ghana, cabbage is popular in the urban and peri-urban areas where it is produced mainly by backyard and market gardeners (Sinnadurai, 1992; Ninsin, 1997). It is consumed primarily as a vegetable and may be used to prepare soup, stew, as stuffing for cake and in salad as part of a main meal. It has high nutritive value supplying essential vitamins, proteins, carbohydrates and vital minerals that are important for proper nutrition (Norton, 1997).

Weeds compete with cabbage for essential nutrients and seriously limit its yield. They may also serve as refuge for insect pests and diseases. Labrada (1994) reported that compared to other arable crops, vegetables compete poorly with weeds during the early part of their life cycle due to initial slow growth.
Cabbage seedlings left unweeded 4-6 weeks after planting (WAP) suffered up to $80 \%$ economic yield loss (Labrada, 1987). According to WAAS (1984), Akobundu (1987), Labrada (1987), and Gupta (1998), weeds must be controlled before 4 WAP to realize the potential yield in cabbage. Despite the importance of weed control in cabbage production, research is limited in defining control regimes for the crop in Ghana. Pre-plant incorporated herbicides provide good control of annual grasses, but broadleaves may be a problem and may require supplementary weed control (Labrada, 1994).

Insect pests such as the diamondback moth (Plutella xylostella [L.]), cabbage webworm (Hellula undalis F.), and cabbage aphid (Brevicoryne brassicae [L.]) also limit cabbage yield in Ghana (Norman, 1992). Application of insecticides has been the principal recourse for control of these pests on cabbage in Ghana (Obeng-Ofori, 2002). However, notwithstanding the financial constraint, 
Agric. Biol. J. N. Am., 2011, 2(6): 921-928

indiscriminate use of pesticides on cabbage and other vegetables in Ghana has resulted in negative impact on the environment and the development of resistance by some of the insect pest species (AduAcheampong, 1997). There is, therefore, the need for novel and alternative pest control strategies that are cheaper to use and also less detrimental to the environment. Extracts from the neem tree, Azardirachta indica A Juss have deterrent and insecticidal properties against over 400 insect pests and could be used for pest control in cabbage (Schmutterer, 1985; Abudulai et al., 2004). The extracts act as contact and stomach poisons, and disrupt the development of eggs, larvae, pupae or prevent moulting of larvae or nymphs (Singh, 1994; Abudulai et al., 2003). Neem also disrupts sexual communication and cause sterility in adult insects (Schmutterer, 1985). The neem tree is ubiquitous in Ghana and can therefore be a cheap source of insecticides for pest control in cabbage and other crops. Moreover, neem is non-toxic to mammals and also benign to nontarget organisms (Ascher, 1993; Abudulai and Shepard, 2003; Abudulai et al., 2004).

The objectives of the present study were to evaluate the effect of weeding regime and application of neem seed extract on insect pests and yield of cabbage.

\section{MATERIALS AND METHODS}

Experimental site: The study was conducted on the research farm of the University for Development Studies at Nyankpala $\left(9^{\circ} 42^{\prime} \mathrm{N}\right.$ latitude, and $0^{\circ} 92^{\prime} \mathrm{W}$ longitude, and $184 \mathrm{~m}$ altitude) near Tamale in the Guinea savannah zone. The area experiences a unimodal rainfall pattern from June to October with a peak occurring in September and an annual total rainfall of about $1022 \mathrm{~mm}$ (SARI, 1994). The soil has a sandy loam texture, developed from Voltaian sandstone and classified as Nyankpala series (SARI, 1994).

Experimental design: Factorial combinations of 3 weeding regimes and 5 neem and insecticide treatments were laid out in randomized complete block design and replicated three times. The neem treatments were $2 \%(\mathrm{w} / \mathrm{v})$ neem seed extract (NSE), $5 \%$ NSE and $10 \%$ NSE, with Karate (Lambda cyhalothrin) as the reference product and watertreated control. Weed treatment levels were weeding every 2 weeks, weeding every 3 weeks and unweeded control.
Raising of cabbage seedlings and land preparation: Cabbage seeds of the variety 'Oxalus' (white cabbage), were obtained from Wunpini AgroProducts Ltd in Tamale and sown on well prepared beds. The field was disc-ploughed to a depth of about $20 \mathrm{~cm}$ in June 2005 and 2006. The seedlings were raised on beds measuring $15 \mathrm{~cm}$ high by $2 \mathrm{~m}$ wide by $3 \mathrm{~m}$ long that were constructed using a hand-hoe. The seedlings were hardened for 3 days by withdrawal of watering before they were transplanted onto field beds four weeks after sowing. The plants were spaced $50 \times 60 \mathrm{~cm}$ on the beds. Organic manure (cow dung) at the rate of $5 \mathrm{t} / \mathrm{ha}$ was worked into the beds 2 weeks before seedlings were transplanted (TP) and NPK (15-15-15) fertilizer was applied at $250 \mathrm{~kg} / \mathrm{ha}$ at transplanting. Sulphate of ammonia was applied as top dress at the rate of 60 $\mathrm{kg} \mathrm{N} / \mathrm{ha}$ at 3 and 6 weeks after transplanting (WAT).

Preparation and application of neem seed extracts: Ripe neem seeds were collected from different trees at Nyankpala near Tamale, de-pulped and allowed to dry under shade for one week. The seeds were weighed into three batches of $20 \mathrm{~g}, 50 \mathrm{~g}$ and $100 \mathrm{~g}$ and ground into powder. Powdered soap was added to each batch at $1,2.5$ and $5 \mathrm{~g}$, respectively and each mixture was soaked in one (1) liter of water and allowed to stay overnight. The mixtures were filtered the next day to obtain the $2 \%$, $5 \%$ and $10 \%(\mathrm{w} / \mathrm{v})$ NSE concentrations. Karate was applied at the recommended rate of $50 \mathrm{ml} / 15 \mathrm{~L}$ knapsack. Spray applications were made starting from 10 days after transplanting, using the CP-15 knapsack sprayer fitted with Tee Jet nozzles. Neem was applied weekly for eight weeks during the season while Karate was applied every two weeks during the period.

Data collection and analysis: Data were collected on crop establishment by counting the number of plants that survived after transplanting at four weeks after planting and at harvest. Baseline density of weed flora data was taken before land preparation by using a $1 \times 1 \mathrm{~m}$ quadrat at five points along the two diagonals of the field and the procedure was repeated at harvest using the scale $0-4$, where $0=$ zero weed $/ \mathrm{m}^{2}, 1=1$ weed $/ \mathrm{m}^{2}, 2=2-5$ weeds $/ \mathrm{m}^{2}, 3=$ $6-19$ weeds $/ \mathrm{m}^{2}$ and $4=\geq 20$ weeds $/ \mathrm{m}^{2}$. Percentage weed occurrence was calculated using:

$\%$ Mean weed occurrence $=\left(F / \sum F+D / \sum D\right) \times 50 \ldots \quad$. Eqn. 1

Where: 
$F=$ frequency of weed species occurrence and $D=$ density of occurrence,

The dry matter of weeds was determined at $3,6,9$ and 12 WAP by oven drying at $80^{\circ} \mathrm{C}$ for 48 hours. Populations of the different insect pests were estimated in-situ by visual counting on two rows of each plot. The insects were sampled before application of insecticides and two days after treatment. Ten randomly selected cabbage heads from each plot were harvested and average weight calculated for yield analysis.

Due to similarity of data points, mean values for the two years were subjected to analysis of variance and treatment means were separated using the least significance difference test at $P=0.05$. The analysis was done using GENSTAT statistical package .

\section{RESULTS AND DISCUSSION}

General observations: None of the interactions of weeding regime and insecticide treatments significantly affected insect pest populations, weed biomass production and cabbage yield. Weeding regime did not significantly $(P=0.05)$ influence plant establishment at 4 WAT, although some of the plants that survived on unweeded control plots were visually of less vigour than plants exposed to more frequent weed control (Table 1). However, season-long weed infestation lowered $(P=0.05)$ plant populations at harvest compared with weed control at every 2 or 3 weeks that supported similar plant populations.

Table 1. Mean number of plants on plots at 4 WAP and at harvest in 2005 and 2006.

\begin{tabular}{|l|l|l|}
\hline Weeding regime & ${ }^{1}$ Mean plant population at 4 weeks & ${ }^{1}$ Mean plant population at harvest \\
\hline 2WAP & $15.6(87)$ & $15.6(87)$ \\
\hline 3WAP & $16.6(92)$ & $15.9(88)$ \\
\hline Unweeded control & $15.7(87)$ & $6.9(38)$ \\
\hline LSD $(0.05)$ & $\mathrm{NS}$ & 5.5 \\
\hline CV\% & 12.5 & 18.9 \\
\hline
\end{tabular}

${ }^{1}$ Figures in brackets indicate \% plant population in each treatment; NS = F-statistic not significant at $P=0.05$.

Weed species and Biomass production : Weed species recorded included broadleaves, grasses, sedges and shrubs (Table 2). The highest number of weed species was recorded for broadleaves followed by grasses, sedges, and shrubs. About fifteen (15) weed species were identified in the broadleaves group constituting about $65.5 \%$ of the total percentage weed coverage at pre-plant and $65.2 \%$ at harvest. The broadleaves weed species recorded included Commelina benghalensis L. , Ageratum conyzoides Linn., Cleome viscosa L., Passiflora foetida L., Conyza sumatrensis Retz., Tridax procumbens Linn., Phyllanthus amarus Shum \&Thonn., Cleome rutidosperma DC., Sida cardifolia Linn., Cassia obtusifolia L. and Amaranthus spinosus Linn. Grasses were the second largest group consisting of three weed species namely Chloris pilosa Shumach, Digitaria horizontalis Willd and Eragrostis tremula Hochst Ex Steud. The sedges and shrubs recorded one species each, Cyperus rotundus Linn. and Icacina trichanta Oliv., respectively and represented the lowest number of weed species recorded on the experimental plots. Weed dominance levels were similar at pre-plant and at harvest for all weed groups. The wide variety of weed species on the field could probably be due to favourable edaphic conditions or high soil fertility (Akobundu, 1995) since groundnut and soybean which are known for their nitrogen fixing abilities were previously planted on the experimental sites. The presence of grasses and sedges was probably due to the continuous cultivation of the land (Akobundu, 1987).

As expected, the effect of weeding regime significantly affected weed biomass production (Figure 1). Weed biomass production was very low when plots were weeded every two weeks compared with those that were weeded after three weeks of planting and the unweeded control. 
Table 2. Mean percentage weed occurrence in cabbage at pre-plant and at harvest in Nyankpala in 2005 and 2006.

\begin{tabular}{|l|l|l|}
\hline Weed species & Pre-plant (\%) & Harvest (\%) \\
\hline a. Grasses & $\mathbf{1 8 . 2}$ & $\mathbf{1 8 . 1}$ \\
\hline Chloris pilosa Schumach & 11.0 & 11.0 \\
\hline Digitaria horizontalis Willd & 4.3 & 4.1 \\
\hline Eragrostis tremula Hochst. Ex Steud. & 3.0 & 3.0 \\
\hline b. Broadleaves & $\mathbf{6 5 . 5}$ & $\mathbf{6 5 . 2}$ \\
\hline Commelina benghalensis L. & 8.7 & 8.8 \\
\hline Ageratum conyzoides Linn. & 11.6 & 11.1 \\
\hline Cleome viscosa L. & 9.3 & 9.6 \\
\hline Passiflora foetida L. & 3.0 & 3.0 \\
\hline Conyza sumatrensis (Retz.) Walker & 2.8 & 3.0 \\
\hline Mullungo nudicaulis Lam. & 5.5 & 4.0 \\
\hline Tridax procumbens Linn. & 1.7 & 2.0 \\
\hline Phylanthus amarus Schum.\& Thonn. & 3.5 & 3.6 \\
\hline Cleome rutidosperma DC. & 1.8 & 2.0 \\
\hline Euphorbia hirta Linn. & 1.7 & 1.0 \\
\hline Pentodon pentadrus (Schum \&Thonn.) Vatke & 8.0 & 8.3 \\
\hline Sida cordifolia Linn. & 2.4 & 2.6 \\
\hline Cassia obtusifolia L. & 2.9 & 1.0 \\
\hline Corchorus olitorius L. & 2.0 & 1.0 \\
\hline Amaranthus spinosus Linn. & 2.9 & 3.0 \\
\hline c. Sedges & $\mathbf{1 2 . 3}$ & $\mathbf{1 2 . 7}$ \\
\hline Cyperus rotundus Linn. & 12.3 & 12.7 \\
\hline d. Shrubs & & \\
\hline Icacina trichanta Oliv. & $\mathbf{4 . 0}$ & $\mathbf{4 . 0}$ \\
\hline & 4.0 & 4.0 \\
\hline & & \\
\hline
\end{tabular}

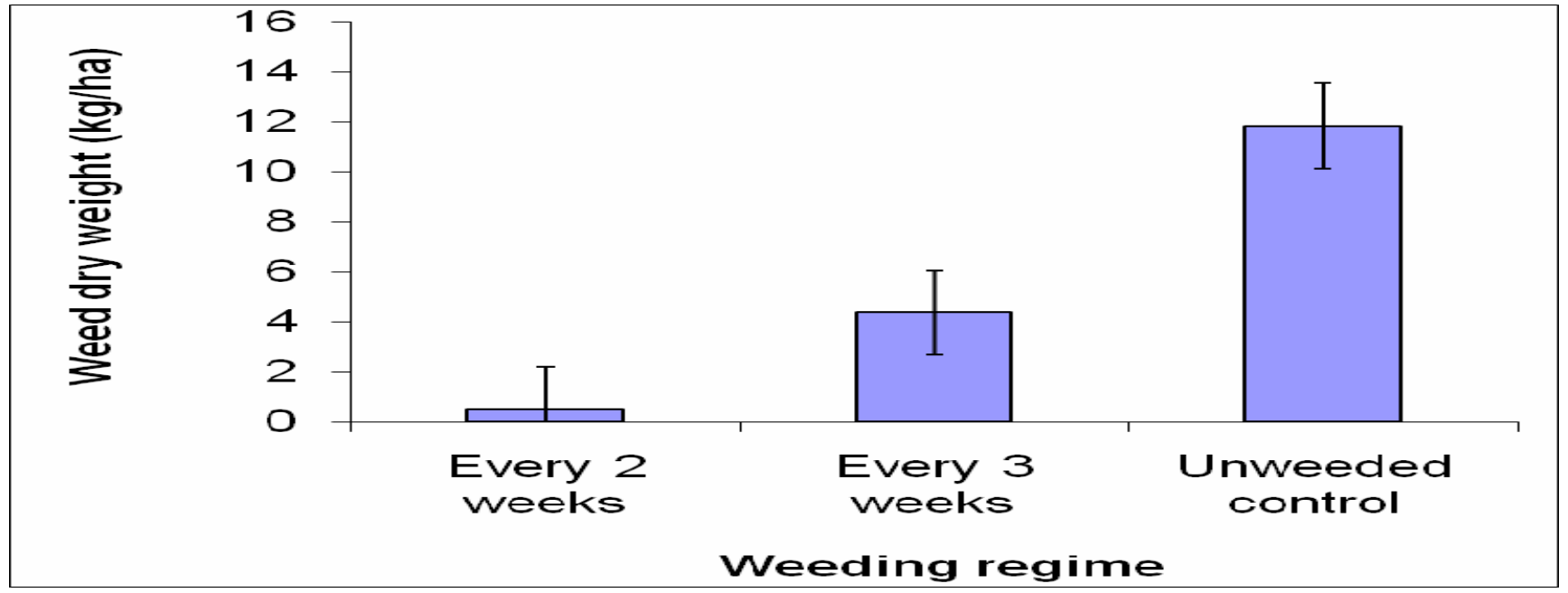

Fig. 1. Weed biomass at harvest as affected by weeding regime. Bars represent SED. 
Table 3. Major pests of cabbage on experimental plots in Nyankpala in 2005 and 2006.

\begin{tabular}{|l|l|}
\hline COMMON NAMES & SCIENTIFIC NAMES \\
\hline Shorthorn grasshopper & Zonocerus variegatus (L.) \\
\hline Snails & Helix pomatia L. \\
\hline Flea beetle & Phyllotreta cruciferae (Goeze) \\
\hline Cabbage webworm & Hellula undalis F. \\
\hline Cricket & Gryllus spp. \\
\hline Diamondback moth & Plutella xylostella (L.) \\
\hline Other caterpillars & \\
Armyworm & Spodoptera sp. \\
Bollworm & Helicoverpa armigera Hübner \\
\hline
\end{tabular}

Table 4. Effect of neem treatments on population of insect and snail pests of cabbage in Nyankpala in 2005 and 2006.

\begin{tabular}{|c|c|c|c|c|c|c|c|c|c|c|c|c|c|c|}
\hline \multirow{3}{*}{ Treatment } & \multicolumn{14}{|c|}{ Pest populations before spray and after spray } \\
\hline & \multicolumn{2}{|c|}{ Grasshoppers } & \multicolumn{2}{|c|}{ Crickets } & \multicolumn{2}{|l|}{ Snails } & \multicolumn{2}{|c|}{ Flea beetles } & \multicolumn{2}{|c|}{$\begin{array}{l}\text { Diamond back } \\
\text { moth }\end{array}$} & \multicolumn{2}{|c|}{ Cabbage webworm } & \multicolumn{2}{|c|}{ Other caterpillars $^{2}$} \\
\hline & $\begin{array}{l}\text { Before } \\
\text { spray }\end{array}$ & $\begin{array}{l}\text { After } \\
\text { spray }\end{array}$ & $\begin{array}{l}\text { Before } \\
\text { spray }\end{array}$ & $\begin{array}{l}\text { After } \\
\text { spray }\end{array}$ & $\begin{array}{l}\text { Before } \\
\text { spray }\end{array}$ & $\begin{array}{l}\text { After } \\
\text { spray }\end{array}$ & $\begin{array}{l}\text { Before } \\
\text { spray }\end{array}$ & $\begin{array}{l}\text { After } \\
\text { spray }\end{array}$ & $\begin{array}{l}\text { Before } \\
\text { spray }\end{array}$ & $\begin{array}{l}\text { After } \\
\text { spray }\end{array}$ & $\begin{array}{l}\text { Before } \\
\text { spray }\end{array}$ & $\begin{array}{l}\text { After } \\
\text { spray }\end{array}$ & $\begin{array}{l}\text { Before } \\
\text { spray }\end{array}$ & $\begin{array}{l}\text { After } \\
\text { spray }\end{array}$ \\
\hline Control & 1.40 & 1.20 & 0.67 & 2.13 & 0.73 & 0.37 & 2.28 & 2.10 & 3.57 & 2.63 & 2.90 & 2.60 & 2.80 & 2.13 \\
\hline $2 \% \mathrm{NSE}$ & 0.90 & 0.83 & 0.53 & 0.93 & 0.70 & 0.33 & 1.47 & 1.27 & 2.60 & 1.07 & 1.90 & 1.10 & 1.47 & 0.97 \\
\hline $5 \%$ NSE & 0.60 & 0.17 & 0.43 & 0.10 & 0.47 & 0.17 & 0.43 & 0.23 & 0.63 & 0.33 & 0.77 & 0.30 & 0.73 & 0.20 \\
\hline $10 \%$ NSE & 0.33 & 0.05 & 0.20 & 0.09 & 0.43 & 0.06 & 0.30 & 0.04 & 0.60 & 0.08 & 0.30 & 0.01 & 0.20 & 0.05 \\
\hline Karate & 1.03 & 0.57 & 0.43 & 0.57 & 0.47 & 0.13 & 0.60 & 0.63 & 0.70 & 0.80 & 1.00 & 0.67 & 0.73 & 0.67 \\
\hline LSD & 0.37 & 0.26 & NS & 0.19 & NS & 0.17 & 0.55 & 0.33 & 0.87 & 0.33 & 0.32 & 0.34 & 0.54 & 0.31 \\
\hline CV (\%) & 23.10 & 24.60 & 25.30 & 13.5 & 28.10 & 43.2 & 20.0 & 20.4 & 28.50 & 17.6 & 12.20 & 19.5 & 24.10 & 20.5 \\
\hline
\end{tabular}

${ }^{a}$ Armyworms and bollworms 
Insect Pests and their Damage on Cabbage: Major insect pests of cabbage recorded were shorthorn grasshoppers (Zonocerus variegatus [L.]), crickets (Gryllus spp.), flea beetles (Phyllotreta cruciferae [Goeze]), the diamondback moth and cabbage webworm. Other insects observed included armyworms (Spodoptera sp.) and bollworms (Helicoverpa armigera [Hübner]). Snails (Helix pomatia L.) were also recorded (Table 3). These pests were also reported by Norman (1992) as major pests of cabbage in Ghana. The diamondback moth is the most important pest of Brassicaceae worldwide (Talekar and Shelton, 1993). These insects fed on leaves and developing heads of cabbage sometimes creating large irregular holes as characteristic feeding damage of grasshoppers, crickets, diamondback moth and snails. Flea beetles gouged out small pits in the leaves giving the leaf a "shot hole" appearance. The cabbage webworm fed on leaves and heads under silken threads. These insects also left their droppings on the leaves and developing heads, further reducing the quality of the heads.

Effect of neem seed extract on densities of insect and snail pests: With the exception of snails and crickets, pest densities before neem spray showed significant differences among the treatments (Table 4). Pest populations were higher in the water-treated control than in the neem and karate treatments.
Application of neem and Karate significantly lowered pest densities than water-treated control. Neem treatment at 5 and $10 \%$ NSE gave a significantly better control of all pests compared with the other treatments, including the pyrethroid insecticide Karate. Other workers have reported that neem treatments are effective for control of cabbage insect pests (Goudegnon et al. 2000; Javaid et al. 2000; Obeng-Ofori and Ankrah, 2002). Goudegnon et al. (2000) reported that 5\% NSE treatment significantly lowered populations of the diamondback moth on cabbage in Benin. The reductions in insect populations were probably due to the insecticidal and/or repellent properties of neem (Schmutterer 1990; Goudegnon et al. 2000; Abudulai et al. 2003). Populations of the insect pests were greater in plots that were treated with Karate than in the neem treatments, which probably showed that the insects were resistant to karate as was reported for another pyrethroid insecticide deltamethrin by Goudegnon et al. (2000).

Effect of weeding regime on insect and snail pest populations: Insect populations generally were more in the unweeded plots than in the weeded plots (Table 5). There were, however, no significant differences in pest densities between plots that were weeded every two (2) weeks and those that were weeded three (3) weeks after transplanting.

Table 5. Influence of weeding regime on pest populations ${ }^{1}$ on cabbage in 2005 and 2006.

\begin{tabular}{|l|l|l|l|l|l|l|l|}
\hline $\begin{array}{l}\text { Weeding } \\
\text { regime }\end{array}$ & $\begin{array}{l}\text { Grass- } \\
\text { Hopper }\end{array}$ & Crickets & $\begin{array}{l}\text { Diamond- back } \\
\text { moth }\end{array}$ & $\begin{array}{l}\text { Cabbage } \\
\text { webworm }\end{array}$ & $\begin{array}{l}\text { Flea } \\
\text { beetles }\end{array}$ & Snails $^{\text {Others }^{\text {a }}}$ \\
\hline 2 WAP & 1.3 & 0.8 & 1.1 & 0.7 & 0.6 & 0.4 & 1.1 \\
\hline 3 WAP & 1.7 & 0.6 & 1.4 & 1.1 & 1.3 & 0.6 & 1.2 \\
\hline $\begin{array}{l}\text { Unweeded } \\
\text { control }\end{array}$ & 2.6 & 3.0 & 3.2 & 2.6 & 2.1 & 1.8 & 2.2 \\
\hline LSD & 0.90 & 0.94 & 0.71 & 0.34 & 0.98 & 0.64 & 1.31 \\
\hline CV \% & 23.20 & 19.9 & 30.10 & 34.8 & 28.60 & 32.40 & 17.40 \\
\hline
\end{tabular}

${ }^{1}$ Data were analyzed using populations taken before spray.

${ }^{\text {a Armyworms and bollworms }}$

Effect of insecticide application on cabbage yield: There were significant differences among treatments on cabbage yield (Figure 2). With the exception of the $2 \%$ NSE treatment, yield was significantly higher in neem-treated plots than in the water-treated control plots. Yield was significantly higher on plots that were treated with $5 \%$ and $10 \%$ NSE compared with plots that were treated with the synthetic insecticide Karate. The 10\% NSE treatment gave the highest cabbage head yield. These results corroborate the findings by Schmutterer (1990),
Goudegnon et al. (2000) and Javaid et al. (2000) who reported greater cabbage head yields in neemtreated than pyrethroid insecticide-treated and control plots.

Effect of weeding regime on cabbage yield: Cabbage head yield was significantly affected by weeding regime. Yields were similar in weeded plots but were significantly lower on unweeded control plots. Cabbage heads from control plots were very small and in some cases heads were not formed 


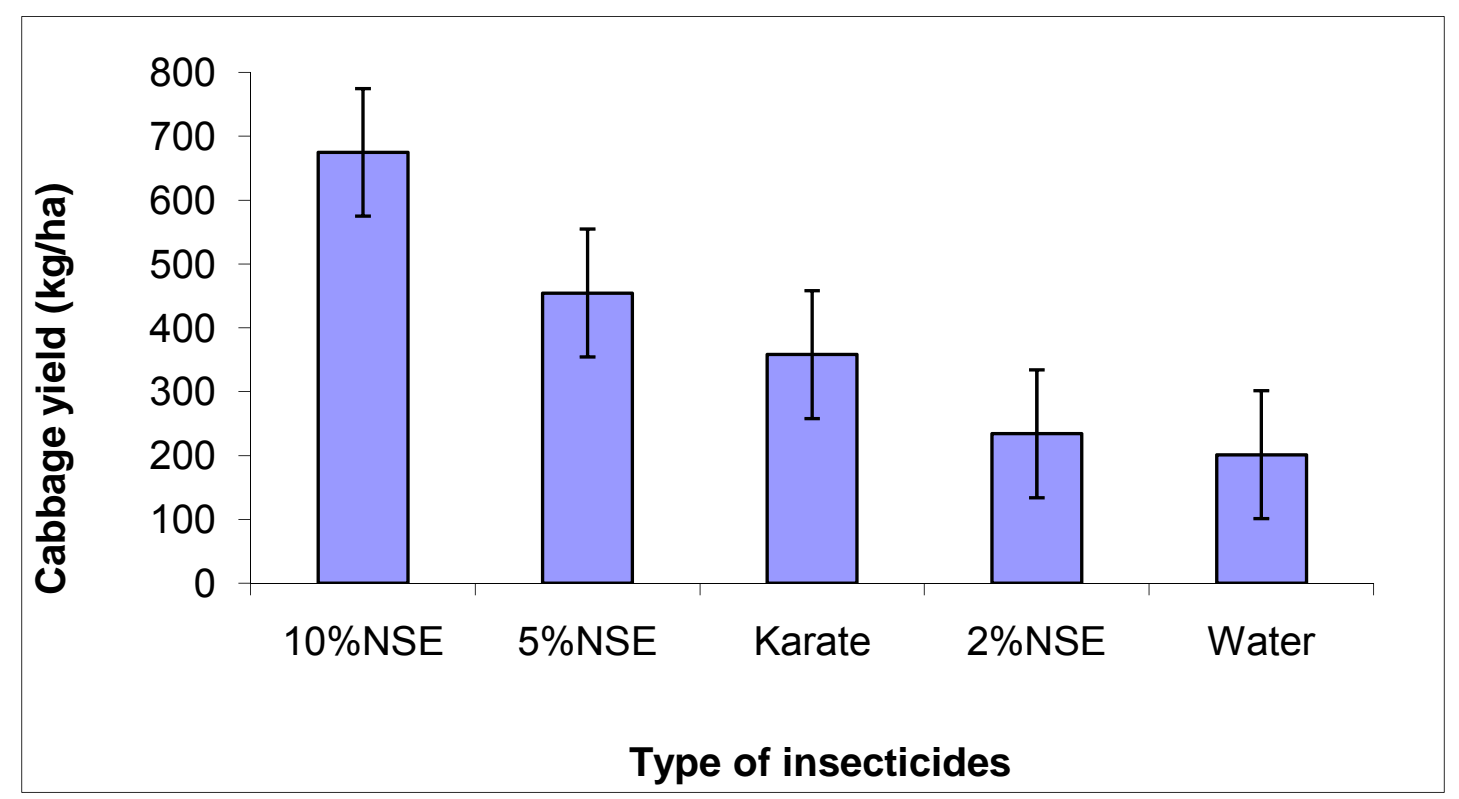

Fig. 2. Effect of insecticide treatment on cabbage yield. Bars represent SED.

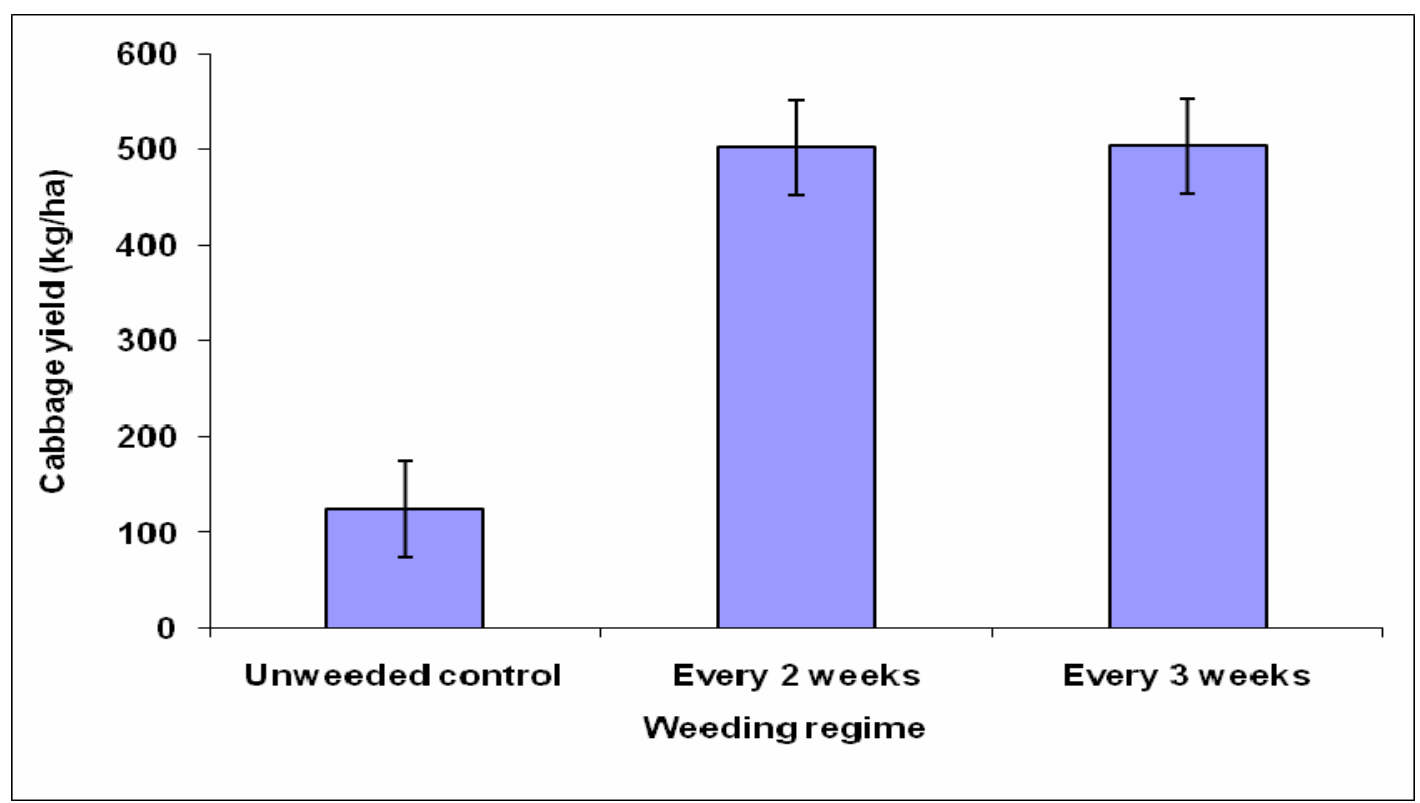

Fig. 3. Effect of weeding regime on cabbage yield. Bars represent SED.

CONCLUSION: The similarity in head yield of cabbage from hoe weeding interventions at every two and three weeks after transplanting suggested the effectiveness of the latter weed control regime to significantly reduce weed competition with the crop below economic threshold. It is therefore recommended that weeds could be controlled as late as at onset of 3 WAP and thereafter given an additional two hand weedings at 6 and 9 WAT to avoid yield loss and make efficient use of resources.
Neem treatments significantly reduced insect and snail pest populations and increased yield more than treating plots with the synthetic insecticide, Karate. Application of $10 \%$ NSE gave the best control, but was similar to $5 \%$ NSE. It is therefore recommended from this study that farmers use $5-10 \%$ NSE to control insect pests on cabbage, with the higher dose applied during periods of good rainfall. The above findings were from neem seed extracts. The seeds are seasonal and may not always be available in time 
of need compared to the leaves that are available all year round. It is therefore recommended that future research should also test neem leaves to increase the options for farmers to use the neem technology so that the leaves can be used for crop protection during periods that the seeds are not available.

\section{REFERENCES}

Abudulai, M. and Shepard, B, M. (2003). Effects of neem (Azadirachta indica A. Juss) on Trissolcus basalis (Wollaston) (Hymenoptera: Scelionidae), a parasitoid of Nezara viridula (L.) (Hemiptera: Pentatomidae). Journal of Entomological Science 38: 386-397.

Abudulai, M., Shepard, B. M. and Mitchell, P. L. (2003). Antifeedant and toxic effects of a neem (Azadirachta indica A. Juss) - based formulation Neemix ${ }^{\circledR}$ against Nezara viridula (L.) (Hemiptera: Pentatomidae). Journal of Entomological Science 38: 398-408.

Abudulai, M., Shepard, B. M. and Mitchell, P. L. (2004). Effects of neem (Azadirachta indica A. Juss) on predators of Nezara viridula (L.) (Hemiptera: Heteroptera: Pentatomidae). Journal of Agricultural and Urban Entomology 21: 9-13.

Adu-Acheampong, R. (1997). Laboratory and field evaluation of neem (Azardirachta indica) for the management of cocoa mirids (Heteroptera miridae). Master of philosophy thesis. University of Ghana, Legon.

Akobundu, I. O. (1987). Weed Science in the Tropics: Principles and Practices. $3^{\text {rd }}$ edition. John Wiley and Sons. New York. 522pp.

Goudegnon, A. E., Kirk, A. A., Schiffers, B., and Bordat D. (2000). Comparative effects of deltamethrin and neem kernel solution treatments on Diamondback moth and Cotesia plutellae (Hym., Braconidae) parasitoid populations in the Cotonou peri-urban area. Journal of Applied Entomology 124:141-144.

Gupta, O. P. (1998). Weed management principles and practice. Published by Agro Botanica. ISBN: 81-8716701-7. pp. 11-35.

Javaid, I., Saifudine, N., Tombolane, L. and Rafael, E. (2000). Efficacy of aqueous neem extracts in the control of diamondback moth, Plutella xylostella (L.) on cabbage. Insect Science and Its Applications 20: 167170.

Labrada R. (1987). Effective chemical control measures in vegetable crops and beans in Cuba. Abstract Ph.D. Theisis Moscow Agricultural Academy. pp18.
Labrada R. (1994). Weed management in vegetable crops. In: Weed Management for Development Countries. Eds: R. Labrada, J.C. Caseley and C. Parker. FAO Plant Production and Protection Paper 120. pp 282291.

Ninsin, D.K. (1997). Insecticide use patterns and residue levels on cabbage (Brassica oleracea var capitata) cultivated within Accra-Tema metropolitant areas of Ghana Master of philosophy thesis, Insect science programe, University of Ghana Legon Accra. pp 85.

Norman J.C (1992). Tropical vegetable crops (C) J.C. Norman, D.T.A Bsc (Agric); Msc (hort.); Dr. Agr. 1992 first published in great Britain1992.pp35.

Norton, G.A. and Conway, G.R. (1997). The economic and social context of pest, diseases and weed problems. In origin of pest, parasites, diseases and weed problems, Ed. By J.M Cherret and G.R. Sagar, Pp 205-26.Oxford; Blackwell scientific.

Obeng-Ofori, D. and D.A. Ankrah. (2002). Effectiveness of aqueous neem extracts for the control of insect pest of Cabbage (Brassica oleracea var. capitata) Agricultural and food science journal of Ghana vol. 1 July 2002.published by the editorial secretariat crop research institute (council for scientific and industrial research). P.O.Box 3785 Kumasi, Ghana.

Schmutterer, H., (1985). Which insect pests can be controlled by application of neem kernel extracts under field conditions? Journal of Applied Entomology 100: 468-75.

Schmutterer, H., (1990). Properties and potential of natural pesticides from the neem tree. Annual Review of Entomology 35:271-298.

Singh, R.P. (1994). Comparison of Antifeedant Efficacy and Extract yield from different parts and ecotypes of neem (Azardiracta indica) trees. In; Proc. $3^{\text {rd }}$ Int. Neem conference, NAIROBI, Kenya. Ed. by Schmutterer, H. Ascher, K.R.S., Eschborn, Dentsche Gesellescharft for Technische Zusammennarbeit. pp185-194.

Sinnadurai, S. (1992). Vegetable cultivation, published by Asempa publisher Christian council of Ghana. Box 919Accra Copy right @ $\odot$ Suppiah Sinnadurai 1992 ISBN 9964-78-141-5.pp 143.

Talekar, N. S. and Shelton, A. M. (1993). Biology, ecology and management of the Diamondback moth. Annual Review of Entomology 38: 275-301.

WAAS.(1984). Crop Losses due to Weeds in Canada and the United States. Weed Science Society of America 67: 582-698. 